\title{
r \\ MANAGEMENT OF ACQUIRED SOFT TISSUE DEFECTS OF GROIN AND GENITALIA
}

\section{Ratnakar Sharma Mir Adnan Samad Kumar Sourav Dogra}

\section{Shaarang Gupta*}

Professor, Department Of General Surgery, Government Medical College Jammu.

Resident, Department of General Surgery, Government Medical College Jammu.

Resident, Department of General Surgery, Government Medical College Jammu.

Resident, Department Of General Surgery, Government Medical College Jammu. *Corresponding Author

ABSTRACT Background: The defects of the groin and the genitalia are complex and pose a challenge to the reconstructive surgeon These defects may arise out of a variety of insults which include - extirpative oncologic surgeries, necrotizing fasciitis, post burn defects, post traumatic defects including road traffic accidents and animal bites etc.

Objectives: To study the epidemiology of the acquired soft tissue defects of the groin and genitalia.

To evaluate the role of various reconstructive modalities for the acquired soft tissue defects of groin and genitalia.

Materials \& Methods: This study was conducted in the Department of Surgery, Govt. Medical College Jammu, J\&K, India and included 25 patients admitted with acquired soft-tissue defects of groin and genitalia over a period extending from November 2018 to October 2019 (Prospective study). Personal and demographic data of the patient was noted.

A detailed history regarding the cause of the defect along with history of trauma, discharge and bleed from the site was taken. Any past history of surgery and irradiation of the region was noted. The patients having soft tissue defects of the groin and genitalia secondary to the release of post burn contracture were subjected to the detailed history as regards cause of burn, treatment taken and time taken for burn wounds to heal. Examination included general physical examination along with the local wound condition which included site, size, discharge, slough, granulation tissue and any exposed vital structures such as vessels/ nerves. A hemogram, assessment of blood sugar, renal function (blood urea nitrogen and serum creatinine), coagulation profile, blood grouping, viral markers, chest x-ray and ECG were done as a part of routine preoperative investigations. Wound swab was sent for culture. Biopsy was taken wherever required. Analysis of report of any previously taken biopsy was done. Split thickness skin grafting was the modality of coverage utilized in $56 \%$ cases followed by flap coverage in $32 \%$ cases. $12 \%$ of the defects were closed primarily.

Results: Majority of the patients had durable coverage of the defects of groin/genitalia and the coverage modality was acceptable to the patient as regards aesthesis and functional outcome. No major complication was encountered in any of the patients.

Conclusion: The reconstruction of the soft tissue defects of groin and genitalia need a meticulous examination and planning of reconstructive modality which may include skin grafting or a flap coverage.

\section{KEYWORDS : Acquired soft tissue defects of groin and genitalia, reconstruction of defects}

\section{BACKGROUND}

The defects of the groin and the genitalia are complex and pose a challenge to the reconstructive surgeon. These defects may arise out of a variety of insults which include - extirpative oncologic surgeries, necrotizing fasciitis, post burn defects, post traumatic defects including road traffic accidents and animal bites etc. Soft tissue defects of the groin and genitalia that cannot be closed primarily can arise out of surgical procedures for malignancies involving this region. ${ }^{1}$ The exenterative procedures involving groin/genitalia may result in large defects where loco regional flaps may be required to close the wound, to fill the dead space and improve wound healing in previously irradiated fields. ${ }^{2}$ Groin dissection is an essential component in the treatment of penile and distal urethral cancers. Unfortunately, the procedure has been associated with significant complications such as wound infection, seroma and skin necrosis leading to wound dehiscence and lymphedema. In an attempt to reduce these complications, skin flaps can be used to cover the groin, rather than closing the groin defect under tension. ${ }^{3}$ Reconstruction of genital/groin defects following radical debridement in necrotizing fasciitis if not closed primarily requires skin grafts, flaps, and urethral reconstruction using Gracilis flaps to reduce morbidity and provide acceptable functional and aesthetic outcomes. ${ }^{4}$ Fournier's Gangrene is a rare rapidly progressive fulminant form of necrotizing fasciitis of genital, perineal and perianal regions, which may extend up to abdominal wall between fascial planes. This polymicrobial infection leads to thrombosis of subcutaneous and cutaneous blood vessels, resulting in severe gangrene of the overlying skin. Treatment is aggressive surgical debridement followed by reconstruction. Primary suturing is often described for small defects. Larger defects may require skin grafting. Soft tissue flaps provide excellent cover for exposed testes. ${ }^{5}$ Genital and groin burns occurred in context of major burns and were rarely isolated. $64.1 \%$ were scald burns, 3.8\% contact burns and $2.6 \%$ electrical burns. ${ }^{6}$ The incidence of groin and genital burns is uncommon due to the deep location between thighs. $56 \%$ patients develop contractures needing surgical release with either local flaps or skin grafts. ${ }^{7}$ Burn injuries to the genitalia in children are usually due to spilling of hot liquids on them. These are usually partial thickness burns. Deep burns of the groin are usually associated with large total body surface area flame burns or immersion injuries. ${ }^{8}$ Animal bites are rare but potentially serious cause of genital trauma and children are the most common victims. Morbidity is directly associated with the severity of the initial trauma. Because patients tend to seek medical care promptly, infectious complications are unusual. Management involves irrigation, debridement, antibiotic prophylaxis tetanus and rabies immunization as well as primary wound closure or surgical reconstruction. Good functional and cosmetic results are possible in the majority of cases. ${ }^{9}$ An increasing number of avulsion injuries of the external male genitalia are being seen because of widespread use of high-speed machinery in the industry and the rapid mechanization of agriculture. They should be treated as surgical emergencies to prevent infection and avoid subsequent complications. In most of the cases the avulsion injury is due to indirect trauma, a loose garment being caught in a fast-moving machine. ${ }^{10}$ Radiation therapy is currently utilized for primary and adjuvant therapy for pelvic tumors which may lead to complex pelvic and groin wounds. Wound debridement and coverage with well vascularized flaps have been established as reliable method to repair complex wounds of pelvic radiation necrosis. ${ }^{2}$

\section{MATERIALS AND METHODS}

The study entailed a prospective study of 25 patients admitted in the Department of Surgery, Government Medical College, Jammu with acquired defects of the genitalia and the groin for a period of 12 months i.e. from $1^{\text {st }}$ November 2018 to $31^{\text {st }}$ October 2019 . The patients were assessed as regards the cause and severity of the defects and managed accordingly. Personal and demographic data of the patient was noted.

A detailed history regarding the cause of the defect along with history of trauma, discharge and bleed from the site was taken. Any past 
history of surgery and irradiation of the region was noted. The patients having soft tissue defects of the groin and genitalia secondary to the release of post burn contracture were subjected to the detailed history as regards cause of burn, treatment taken and time taken for burn wounds to heal. Examination included general physical examination along with the local wound condition which included site, size, discharge, slough, granulation tissue and any exposed vital structures such as vessels/ nerves. All the patients underwent pre-operative investigations for requisite anaesthesia.

Split thickness skin grafting was the modality of coverage utilized in $56 \%$ cases followed by flap coverage in $32 \%$ cases. $12 \%$ of the defects were closed primarily. Flap division and inset if required was done after interval of three weeks. Patients were followed-up periodically in the post-operative period.

\section{INCLUSION CRITERIA}

The study included all the patients with soft tissue defects of groin and genitalia needing coverage presenting in the OPD/Emergency of Department of General Surgery, GMC Jammu.

\section{EXCLUSION CRITERIA}

Patients with acquired soft tissue defects of groin/genitalia with active malignant disease.

\section{RESULTS}

TABLE 1-AGE DISTRIBUTION OF PATIENTS

\begin{tabular}{|c|c|c|}
\hline AGE GROUP & NO. OF PATIENTS & PERCENTAGE (\%) \\
\hline$<10$ years & 2 & 8 \\
\hline $11-20$ years & 2 & 8 \\
\hline $21-30$ years & 4 & 16 \\
\hline $31-40$ years & 4 & 16 \\
\hline $41-50$ years & 6 & 24 \\
\hline $51-60$ years & 7 & 28 \\
\hline Total & 25 & 100 \\
\hline
\end{tabular}

Maximum number of patients were in the age group of 51- 60 years (28\%) followed by $41-50$ years of age $(24 \%)$. The average age of the patients was 38.04 years.

Out of the 25 patients, $21(84 \%)$ were male and $4(16 \%)$ were female making a male: female ratio of about 5.25:1. Maximum patients requiring coverage for acquired soft tissue defects of groin and genitalia were either labourers or farmers (24\%), followed by office goers and electricians $(20 \%)$.

\section{TABLE 2-CAUSES OF DEFECT}

\begin{tabular}{|l|c|c|c|}
\hline Cause & $\begin{array}{c}\text { No. of } \\
\text { patients }\end{array}$ & Male & Female \\
\hline $\begin{array}{l}\text { Release of post } \\
\text { burn contractures }\end{array}$ & 8 & 5 & 3 \\
\hline $\begin{array}{l}\text { Defects due to } \\
\text { electric burns }\end{array}$ & 5 & 5 & Nil \\
\hline $\begin{array}{l}\text { Fournier's } \\
\text { Gangrene }\end{array}$ & 6 & 6 & Nil \\
\hline Trauma & 3 & 3 & Nil \\
\hline Excision of tumors & 2 & 1 & 1 \\
\hline Animal bites & 1 & 1 & Nil \\
\hline Total & 25 & 21 & 4 \\
\hline
\end{tabular}

Release of post burn contracture was the most frequent cause of soft tissue defects of groin/genitalia (32\%) followed by Fournier's Gangrene (24\%).

\section{TABLE 3-SITE OF DEFECTS ACCORDING TO CAUSE}

\begin{tabular}{|c|c|c|}
\hline Site & Causes & No. of patients \\
\hline \multirow[t]{4}{*}{$\begin{array}{c}\text { Groin defects } \\
\mathrm{n}=17\end{array}$} & $\begin{array}{l}\text { Release of post } \\
\text { burn contracture }\end{array}$ & 7 \\
\hline & Trauma & 3 \\
\hline & Electric burn & 5 \\
\hline & Tumor excision & 2 \\
\hline \multirow[t]{2}{*}{ Genital defects $n=6$} & $\begin{array}{l}\text { Release of post } \\
\text { burn contracture }\end{array}$ & 1 \\
\hline & $\begin{array}{l}\text { Fournier's } \\
\text { Gangrene }\end{array}$ & 4 \\
\hline$($ Scrotal $n=1)$ & Animal bite & 1 \\
\hline $\begin{array}{c}\text { Combined defects } \\
(\text { Groin }+ \text { Penis }+ \text { Scrotum }) n=2\end{array}$ & $\begin{array}{l}\text { Fournier's } \\
\text { Gangrene }\end{array}$ & 2 \\
\hline
\end{tabular}

In our study $68 \%$ of patients had defects in the groin with release of post burn contracture being the most common cause of the defect involving groin $(28 \%)$

Split thickness skin grafting was the modality of coverage utilized in $56 \%$ cases followed by flap coverage in $32 \%$ cases. $12 \%$ of the defects were closed primarily.

\section{TABLE 4-TYPE OF COVERAGE AS PER DEFECT}

\begin{tabular}{|c|c|c|}
\hline $\begin{array}{l}\text { COVERAGE } \\
\text { MODALITY }\end{array}$ & CAUSE OF DEFECTS & $\begin{array}{c}\text { NO. OF } \\
\text { PATIENTS }\end{array}$ \\
\hline \multirow[t]{2}{*}{ Primary closure } & Animal bite & 1 \\
\hline & Trauma & 2 \\
\hline \multirow[t]{4}{*}{ STSG } & Post burn contracture & 8 \\
\hline & $\begin{array}{l}\text { Defects due to electric } \\
\text { burns }\end{array}$ & 3 \\
\hline & Fournier's Gangrene & 2 \\
\hline & tumor Excision & 1 \\
\hline \multirow[t]{2}{*}{$\begin{array}{l}\text { Pedicled ALT } \\
\text { Flap }\end{array}$} & $\begin{array}{l}\text { Defects due to electric } \\
\text { burn (Groin) }\end{array}$ & 2 \\
\hline & $\begin{array}{l}\text { Defects due to tumor } \\
\text { excision (Groin) }\end{array}$ & 1 \\
\hline \multirow[t]{2}{*}{$\begin{array}{l}\text { Medial Thigh } \\
\text { Flap }\end{array}$} & $\begin{array}{l}\text { Fournier's Gangrene } \\
\quad \text { (scrotum) }\end{array}$ & 4 \\
\hline & tumor excision & 1 \\
\hline
\end{tabular}

Medial thigh flap was the most common flap used for coverage of defects of groin and genitalia; $(n=5)(20 \%)$ followed by pedicled ALT flap; $(n=3)(12 \%)$.

Patients requiring skin graft as a modality of coverage took 3 weeks to recover whilst the recovery period was 6 weeks in the patients undergoing flap coverage as a reconstructive modality.

No major complication was noted in any of the patients. Partial loss of skin graft was observed in 2 cases $(8 \%)$ which were managed by dressings only. Marginal flap necrosis was seen in one case (4\%) of Fournier Gangrene of scrotum which was managed by debridement and flap advancement. None of the patients in our study required a second surgical procedure for any complication.

\section{DISCUSSION}

Several diseases affect the genitalia and the groin region which may result in tissue loss, functional disability and cosmetic disfigurement. This can have a significant impact on patient's quality of life necessitating surgical intervention in many instances.

In our study, 25 cases of defects arising out of various causes involving groin and the genitalia needing coverage were included. Maximum numbers of the patients were in the age group ranging between $51-60$ years accounting for $28 \%$. Mean age of the patients was 38.04 years. The youngest patient was 7 years old male and the oldest was 60 years old male.

The relationship between age and soft-tissue defects of groin and genitalia owing to various reasons has been established in studies by other authors. ${ }^{1,12,13,14}$ The males outnumbered females in our study group and contributed for $84 \%$ of the cases. This finding goes well with other study groups. ${ }^{15,16}$

In our study, Out of 25 patients requiring the coverage for soft tissue defects of groin and genitalia, release of post burn contracture accounted for the defects in 8 patients (32\%), Fournier's Gangrene accounted for the defects in 6 patients $(24 \%)$, electric burns were found to be the cause of defects in 5 patients $(20 \%)$ whereas trauma, tumor excision and animal bites were the causes in 3, 2 and 1 patients $(12 \%$, $8 \%$ and $4 \%$ ) respectively. Various etiologies for soft tissue defects of groin and genitalia have been put forward in studies of various authors. ${ }^{12,17}$

In our study, most of the patients were either farmers or labourers $(n=6)$ accounting for $24 \%$ of the patients, 5 were office goers and 5 were 
electricians accounting for $20 \%$ each. In addition, $4(16 \%)$ patients were school going children, $3(12 \%)$ were housewives whereas $2(8 \%)$ were college students.

Out of 25 patients in our study, $17(68 \%)$ patients had defects in groin, 6 $(24 \%)$ had genital defects and 2 patients $(8 \%)$ had combined groin and genital defects. Of the patients with genital defects, $5(20 \%)$ had penoscrotal defects and $1(4 \%)$ had scrotal defect alone. The site of defects of the groin and genitalia due to various causes have been studied by the studies carried out by other authors. ${ }^{18,19}$

In our study, skin grafting was the most common modality employed for the coverage of the soft tissue defects in 14 cases (56\%) followed by flap coverage in 8 cases $(32 \%)$ and primary closure after tissue mobilization in 3 cases $(12 \%)$. The role of various coverage modalities for soft tissue defects of groin and genitalia has been established in other studies too.

Flap coverage was employed as a coverage modality of soft tissue defects in our study in 8 patients $(32 \%)$. Pedicled Anterolateral Thigh flap was utilized as a coverage modality in 3 patients (12\%) out of which 2 patients had groin defects due to electric burn and 1 patient had a groin defect arising out of tumor excision. Medial Thigh flap was used for scrotal reconstruction in 5 cases $(20 \%)$ out of which 4 patients had soft tissue defects due to Fournier's gangrene whereas 1 patient had a groin defect following tumor excision. Various authors in their studies have utilized a variety of flaps for coverage of soft tissue defects of the groin and genitalia. ${ }^{11,1,2,21,2,23,2,24,25}$

In our study partial graft loss was observed in 2 cases (8\%) of split Thickness Skin Grafting while as marginal flap necrosis was observed in 1 case $(4 \%)$ of Medial Thigh flap. Graft loss was managed with saline dressings while as marginal flap necrosis was managed with debridement and flap advancement. None of the patients with complications required a second surgical procedure for their management. Various authors in their studies on reconstruction of acquired soft tissue defects of groin and genitalia have put forth the various complications of reconstructive modalities. ${ }^{5,10,19,20,21,26}$

\section{CONCLUSION}

In conclusion, acquired soft tissue defects of groin and genitalia are encountered by emergency surgical team and plastic surgeons. The reconstruction of such defects requires meticulous assessment of the defect so that the reconstructed part is aesthetically and functionally acceptable. A variety of reconstructive modalities in form of various procedures such as primary closure, split thickness skin grafting, flap coverage are available.

\section{PLATES}

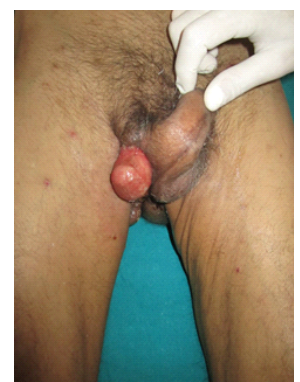

Fig. 1-A Exposed Right Testis Post Fournier Gangrene Debridement

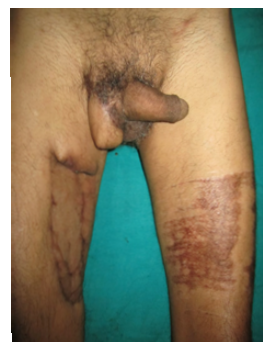

Fig. 1-C Reconstructed Scrotum with well settled Skin Graft and Healed Donor Site

Fig. 1-B Perforator Based Medial Thigh Flap elevated with STSG of Secondary Defect

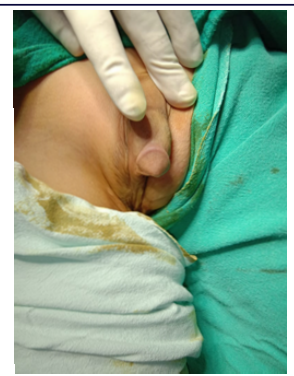
scrotal contracture
Fig. 2-A Post-Burn Peno-

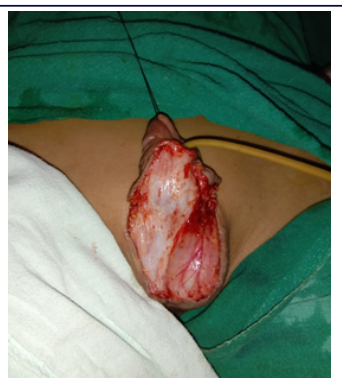

Fig. 2-B Post-release penoscrotal defect

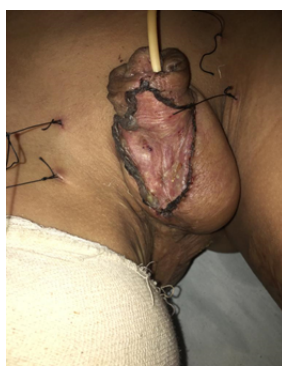

Fig. 2-C Well-Settled Skin Graft

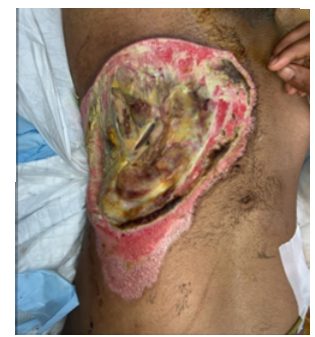

Fig. 3-A Post Electric Burn Defect Left Groin

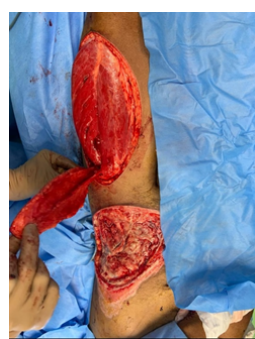

Fig. 3-B Wound Debridement with Elevation of Left Pedicled ALT Flap

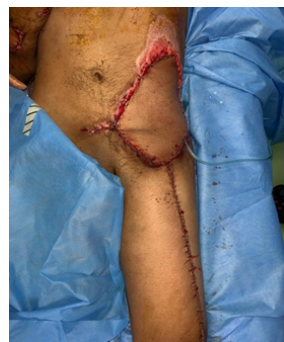

Fig. 3-C Flap Inset With Primary Closure Of Donor Flap Site

\section{REFERENCES}

1. Salgado JC, Chim H, Skowronski PP et al. Reconstruction of acquired defects of vagina and perineum. Semin Plast Surg. 2011;25(2): 155-162

2. Mathes SJ, Hurwitz DJ. Repair of chronic radiation wounds of the pelvis. World J. Surg. 1986; 10(2): 269-80.

3. Gupta AK, Kingsly PM, Jeeth IJ et al. Groin reconstruction after inguinal block dissection. Indian J Urol. 2006; 22: 355-9.

Mallikarjuna MN, Vijayakumar A, Patil VS et al. Fournier's Gangrene: current practices. International Scholarly Research Network Surgery. 2012; 2:14-21.

5. El Saady MM, Ahmed SK, Mansour RA et al. Different modalities of reconstruction in Fournier gangrene. Z.U.M.J. 2013; 19: 649-656.

Angel C, Shu T, French D et al. Genital and perineal burns in children: 10 years of experience at a major burn center. J Pediatr Surg. 2002;37(1): 99-103.

8. Alghanem AA, McCauley RL, Robson MC et al. Management of pediatric perineal and genital burns: twenty-year review. J Burn Care Rehabil. 1990; 11(4): 308-11.

9. Gomes CM, Ribeiro-Filho L, Giron AM et al. Genital trauma due to animal bites. J Urol. 2001; $165(1): 80-3$

10. Tripathi FM, Sinha JK, Bhattacharya Vet al. Traumatic avulsion of penile and scrotal skin. British Journal of Plastic Surgery. 1982; 35:302-303.

11. Turley CB, Cutting P, Clarke JA. Medial fasciocutaneous flap of thigh for release of post-burn groin contractures. British Journal of Plastic Surgery. 1991; 44:36-40.

12. Lin CT, Chen LW. Using a Free Thoracodorsal Artery Perforator Flap for phallic reconstruction - a report of surgical technique. J Plast Reconstr Aesthet Surg. 2009; 62(3): 402-8.

13. Yii NW, Niranjan NS. Lotus Petal Flaps in vulvo-vaginal reconstruction. Br J Plast Surg. 1996; 49:547-554.

14. Wolf, JR. JS, Turzan C, Cattolica EV et al. Dog bites to male genitalia: characteristics, management and comparison with human bites. The Journal of Urology. 1993; 149: 286- 
5. Korambayil PM, Ambookan PV, Dilliraj VK. Superiorly based perforator plus flap for inguinal defects. Plast Aesthet Res. 2014; 1:89-93.

16. Ikramullah, Ullah I, Iqbal Q et al. Fournier gangrene: Management experience of 39 cases. J Postgrad Med Inst. 2017;31(4): 371-7.

17. Alwaal A, McAninch, Harris CR et al. Utilities of split-thickness skin grafting for male genital reconstruction. Urology. 2015; 86: 835-839.

18. Manchanda RL, Singh R, Keswani RK et al. Traumatic avulsion of scrotum and penile Manch Br J Plast Surg. 1965; 8:97-103.
skind

19. Saleem A, Mohsin M, Zargar HR et al. Reconstruction of soft tissue defects in Fournier's gangrene at a tertiary care centre. Int J Res Med Sci. 2016; 4(10): 4314-4318.

20. Steyn G, Giaquinto-Cillers MGC, Reiner $\mathrm{H}$ et al. Fournier's gangrene: challenges and pitfalls for genital reconstruction from a tertiary hospital in South Africa. Wound Healing Southern Africa. 2017; 10:29-34.

21. Ahmad I, Maurya RK, Mahmud MK et al. Medial thigh flap: an eminent method for reconstruction of scrotal defect following Fournier's gangrene. Turk J Plast Surg. 2018; 26:116-21.

22. Nthumba P, Hansen E, Jami M et al. Reconstruction of complex post-traumatic perineal/pelvic defects using Pedicled Anterolateral Thigh Flap in a child. Ann. Afr. perineal/pelvic defects using Pedicled Anterolateral Thigh Flap in a child. Ann. Afr.
Surg. 2015; 12(1): 56-58.

23. Bharath SP, Madhusudan G, Manjunath S. Pedicled Anterolateral Thigh Flap for Contralateral Groin Composite Defect. Indian J Plast Surg. 2010; 43(1): 103-105

24. Agarwal AK, Gupta S, Bhattacharya $\mathrm{N}$ et al. Tensor fascia lata flap reconstruction in groin malignancy. Singapore Med J. 2009; 50(8): 781-4.

25. Kuvat SV, Yanar H, Bicer A et al. Reconstruction of complex groin defects with inferior epigastric artery- based rectus abdominis muscle flaps: report of two cases. Ulus Trauma Acil Cerrahi Derg. 2011; 17: 273-276.

26. Yang J, Ko SH, Oh SJ et al. Reconstruction of a perineoscrotal defect using bilateral medial thigh fasciocutaneous flaps. Arch Plast Surg. 2013;40: 72-74 